Etnográfica

Revista do Centro em Rede de Investigação em

Antropologia

vol. $13(2) \mid 2009$

Vol. $13(2)$

\title{
Fent barri: heritage tourism policy and neighbourhood scaling in Ciutat de Mallorca
}

Fent barri: políticas de turismo patrimonial e configuração da escala do bairro na Cidade de Maiorca

\section{Marc Morell}

\section{(2) OpenEdition}

\section{Journals}

Electronic version

URL: https://journals.openedition.org/etnografica/1136

DOI: 10.4000/etnografica. 1136

ISSN: 2182-2891

\section{Publisher}

Centro em Rede de Investigação em Antropologia

\section{Printed version}

Date of publication: 1 November 2009

Number of pages: 343-372

ISSN: 0873-6561

\section{Electronic reference}

Marc Morell, "Fent barri: heritage tourism policy and neighbourhood scaling in Ciutat de Mallorca", Etnográfica [Online], vol. 13 (2) | 2009, Online since 16 May 2012, connection on 10 February 2022 URL: http://journals.openedition.org/etnografica/1136 ; DOI: https://doi.org/10.4000/etnografica. 1136

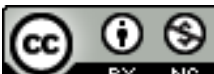

Etnográfica is licensed under a Creative Commons Attribution-NonCommercial 4.0 International License. 


\section{Fent barri: heritage tourism policy and neighbourhood scaling in Ciutat de Mallorca ${ }^{1}$}

Marc Morell

This paper explores the meanings of the local expression fer barri (neighbourhood making) in a gentrifying area located in the Historic Centre of Ciutat de Mallorca (Spain). After closely examining the relation of fer barri with tourism in Mallorca, I analyse the tensions between the urban planning schemes unleashed by the public authorities upon this heritage-loaded territory and the practices of its inhabitants. I argue that the concept of neighbourhood scaling best accounts for the social relations that this suburban context embodies, given the hierarchy of forces impinging on it (urban, regional, national, global). Urban policy plans and organised residents scale the neighbourhood in conflictual terms. Some follow a tourism-dependent logic and try to promote the neighbourhood along the lines of heritage, its centrality or by setting up large events. In addition to State-led policies, tourism businesses and real estate enterprises, urban movements often depicted as oppositional groups have their own understanding of fer barri. This is an understanding of contradictory kind since in their attempts to contest capital accumulation by placing a value on the neighbourhood, urban movements can also unintentionally pave the way for both renewal and gentrification. A thorough analysis of the local term fer barri therefore reveals contrasting projects of neighbourhood scaling.

KEYWORDS: gentrification, heritage tourism, neighbourhood renewal, scale and social organisation, urban movements.

I I want to thank the Programa de Beques Doctorals (Conselleria d'Economia, Hisenda i Innovació Govern de les Illes Balears) for funding my research; and especially Patrick Neveling and Carsten Wergin for encouraging me to publish the present text, for giving me the advice I required and for language editing the paper. Alex Miquel (Universitat de les Illes Balears), Jaume Franquesa (University of Toronto), Olsi Lelaj (Universitas Faberfacta Optime) and an anonymous peer-reviewer for Etnográfica provided insightful comments. Finally, I am grateful to Eleanor Lobb for proofreading the English. The usual disclaimers apply. 


\section{INTRODUCTION}

Between the rubble and building sites of an area subject to renewal in downtown Ciutat de Mallorca (from here on Ciutat, the capital city of the Balearic Islands, Spain), ${ }^{2}$ just on the corner of one of the shadowy half-inhabited squares where a group of youngsters illicitly sell drugs, stands Ca na Pepa (Pepa's place), one of the few groceries left in the Historic Centre. Inside, a gloomy atmosphere shrouds the parsimonious activity of Pepa, the 63-year-old grocer, who is preparing a ham sandwich. Opposite the counter - lavishly stacked with all kinds of drinks and food supplies - and against a patinated wall, sit three women, the youngest of whom has just turned 70. The four of them engage in what seems to be a competition as to who has most illnesses and who has visited the doctor within the last fortnight. While I linger, I entertain the idea that it is not only the ancient walls and street layout that confer a sense of vanishing history to the Historic Centre of Ciutat but, more importantly, the ageing population that dwells here.

In August 2008, Pepa reached a deal with one of the many developers active in the area. He had already bought up the entire building flat by flat from people who had moved out of Es Barri ${ }^{3}$ in the past three decades. Pepa is the last to leave but plans to retire at 65 and is therefore determined to run her business for two more years from premises in the basement opposite her old shop. It will not be easy for her to leave for good when the time comes as all she knows in life, she proudly states, is to fer barri (make neighbourhood). The three women sitting there agree. Their main entertainment, they unanimously state, is indeed to visit Pepa and fer barri. To them, this means gossiping, establishing mutual relations of advice, support and aid (e.g. from giving credit to reading letters to the illiterate).

From an analytical perspective, their version is about fostering neighbourly relations on a daily basis. Moreover, in Catalan (one of the languages spoken in Mallorca), fer barri is a powerful idiom and as we will see it is also highly flexible. There are variants such as fer ciutat (city making) or fer país (country making) and the concept has often been used by authorities to rule people by engaging them morally under one collective will. Because of its multi-purpose

2 Ciutat is also known as Palma. Both terms are correct. I choose Ciutat due to its political implications: as a space for public debate, civil rights claims and citizen action.

3 Literally "The Neighbourhood", as people at Ca na Pepa refer to their neighbourhood. In this paper, I use the expression Es Barri to delineate a "lived territory" that is contained within a multiplicity of borders set up by changing urban policies, historical developments and oppositional organisations. Many of these have introduced a new name for the neighbourhood often indicating their understanding with political connotations. In fact, this plurality of names and borders is a reflection of the numerous contests over the territory I am dealing with. Es Barri, and this is of interest to social anthropology, is not a precise geographic delimitation but rather refers to the spatialisation of social relations that is best accounted for with the multiplicity of borders and names the area receives. 
quality, the expression fer barri is used by different groups present in the neighbourhood. Differently from the idea held by those who assemble in $\mathrm{Ca} n a$ Pepa, federations of small and medium businesses also gather around the fer barri issue and promote it as an activity primarily based on shopping in the commercial thoroughfares that border the neighbourhood. In their notion, buyers do not necessarily need to be neighbours "to make neighbourhood". To complicate the situation further, an urban renewal scheme that has been in place for the last 20 years also draws on the power of fer barri. In this case, it is about positively explaining the improvements that have taken place. Finally, fer barri has always been a strategy of the so-called social movements opposing governmental policies and also, since its inception, the urban renewal schemes. The "associations of neighbours" active in Ciutat draw on this ideal when they organise their festes (celebrations). Even the moviment okupa (squatter movement) of Ciutat has its own idea of fer barri.

Thus, Pepa and her clients are not alone in the making of the neighbourhood. Rather, there is a puzzling set of ideas and claims over economic and political realities that are built around the notion of fer barri. This paper takes on both the plurality of engagements towards the making of the neighbourhood and the particular geographical and social scale that is at stake. Since the neighbourhood scale, and the relations that constitute it, serve as the point of reference for all groups of actors - despite their significantly diverse interests - it is important to stress the power dimension inherent in these contestations. As I will argue, the positions the different actors hold are strongly shaped by their relations to and notions of the scaling process they consider best for their group.

Unlike earlier approaches in social anthropology that defined scale according to the "size dichotomy" of small-scale societies as opposed to large-scale ones, I argue that the interesting issue is the scaling process in itself. As I will show, the old women in Ca na Pepa and the developers active in Es Barri conflict over the very same idea, the illusion of social proximity. Thus, following Hannerz, I look at the mutual imaginations people hold of others who are positioned in what they perceive as either large-scale or small-scale social systems according to the idea that "the grass is always greener on the other side of the fence" (Hannerz in Berreman et al. 1978: 239). Hannerz himself extends this observation by questioning the existence of smallness and demands a thorough study of its construction in the following quote: "If under certain circumstances there is a strain toward intimacy in larger-scale social structures, what means may people use to create an illusion of smallness?" (Hannerz in Berreman et al. 1978: 239). My enquiry tackles the illusion of smallness and its manifold material manifestations by evaluating the different dimensions of fer barri.

Since notions of actors about Es Barri are at the same time grounded in different practices of neighbourhood-making and in its scaling projects, these "need to be analysed as based on decision-making processes [...] made within 
groups, institutions, industries and other forms of social organisation" (Neveling and Wergin 2009, this volume). The following ethnographic account analyses the competing practices that socially organise Es Barri's future in light of the strong tourism and land planning policies at work in Ciutat's Historic Centre (from here on Centre). However, before contextualising the position of Es Barri within the scalar structure of regional tourism, I will briefly outline my approach to scale in this paper.

Scale is a central issue in the field of social anthropology and at the very epistemological core of the discipline. ${ }^{4}$ Barth (1978) researched scale at the systemic level meaning that social organisation is a result of dependency relations of different scales and that the aggregation of these relations both reflects on and generates culture. Thus, the task of social anthropology is to write ethnographies that show how real people organise their lives along different scales of complexity and how they relate to the complex, large-scale structures of contemporary societies (Barth 1978: 258). This understanding applies perfectly well to the variegated applications of fer barri outlined above. The task of ethnography in such a contested field of claims on fer barri is to achieve the right balance between agency and structure, as the inquiry into the concept unveils both the ways of actively making the neighbourhood and the historical understandings of how the neighbourhood ought to be made.

Both anthropology and geography recognise the embeddedness of the political, the economic, the social and the cultural. My brief analysis of fer barri in Ciutat indicates that scale is a central analytical tool to deal with this embeddedness. As Rankin (2003) argues, one of the central concerns of anthropology is the relation of the local to the global, whereas geography assumes the task of researching on the political economies of place and scale. But recent debates in geography indicate that the scale question seems to methodologically come apart. In these debates, scale appears in many, not necessarily complementary, ways: (1) As a social construction, generated by productive, reproductive and consumption processes (Marston 2000); (2) as something made real by way of interpreting dynamic and complex relations in a determined context (Howitt 2000); (3) as the result of the dynamics within the scalar hierarchy (Brenner 2001); (4) and as determining its own social content (Manson 2008). ${ }^{5}$

4 The capacity to systemically explain the complexity of social reality from the observation and the analysis of concrete cases has been a major concern in social anthropology. This problematic holds a preferential place in anthropological writing, particularly with regards to the fix and flow of capital, to the grounding of research and to the modernisation dilemmas, as well as to the relation between the local and the global (for variations of approaches to the subject see Wolf 1982; Hannerz 2003; Tsing 2000; Herzfeld 2001; Comaroff and Comaroff 2003; and Knauft 2006).

5 As a result of ardent discussions (e.g. Marston 2000; Brenner 2001; and Marston and Smith 2001 ) there are authors who advocate a flat ontology based on the social network theory (Marston $e t$ al. 2005). 
The projects that organise around fer barri serve to make us think about these methodological definitions of scale. Although the different concepts of fer barri range from comprehensive urban renewal and gentrification to issues of re-establishing local empowerment (cf. Whitehead 2003), they must be regarded as threading into each other because they generate a common, contentious field of reaping and profiteering, celebration and resistance, organisation and survival. As I will show in the following analysis of the regional political economy of tourism in the Historic Centre and its impact on urban planning schemes and neighbourhood initiatives, these projects of fer barri are practices that reflect and generate the neighbourhood scale in multifarious ways: as a site of social reproduction and social consumption (Castells 1991 [1972]), as the urban outcome of scale-fragmentation (Uitermark 2002) and as a site of the uneven development of capital (Smith 1984).

So far, I have outlined the existence of several projects that make of the neighbourhood a controversial scale in the making, that is, I do not simply take this scale as a given. In addition to the agencies encountered throughout my field research there are other forces that shape, and to a certain extent limit, the practices of the different groups of actors that scale the neighbourhood. The following section deals precisely with the regional political economy of tourism and how this industry is involved in the scaling of the neighbourhoods of the Historic Centre.

\section{TOURISM AND THE HISTORIC CENTRE}

Mallorca is a major tourist destination in the Mediterranean. Tourism is one of the two leading industries and actually the main foundation of the second one, construction and real estate activities, today classified as a booming independent economic sector. Despite the emerging global economic crisis, in 2008 the Balearic Islands received 10,288,958 visitors (Frontur 2008). Tourism contributed to around $80 \%$ of the GDP and directly employed about 30\% of the working population. Depending on the season, the catering and hospitality sectors officially had between 43,217 and 11 1,882 workers (Institut d'Estratègia Turística 2008) out of a total population of $1,072,844$ inhabitants (Boletín Oficial del Estado 2008).

The particularity of tourism in the Balearics is best defined by well-rooted academic expressions such as "mass tourism" and "balearisation". ${ }^{6}$ The first expression refers to the high number of visitors and the industry's increasing economic importance (e.g. Shaw and Williams 2002 [1994]), but not necessarily to expenditure per tourist. The second expression instead refers to

6 As Manera and Garau-Taberner (2009) demonstrate, by the mid-1960s the region was a mass tourism pioneer. 
changing patterns of land use and changes in social practices in order to meet the demands of "mass tourism" (e.g. Selwyn 2000). Local scholars from the Balearics have split these touristification processes into periods corresponding to specific "booms".

According to Rullan Salamanca (1999), Blázquez et al. (2002) and Valdivielso (2005) the first boom started in the 1960s. It was a period of incipient mass tourism and urbanisation (especially of the coastline) which peaked just before the 1973 oil crisis. In 1964, during this first boom period, the core of the Centre of Ciutat was declared an "Artistic and Historic Area" and received continuous investment. But the margins of the Centre suffered severely from disinvestment and were dragged into filtering processes of decay. ${ }^{7}$ The second boom occurred simultaneously with the peak of globalisation of the 1980s. The number of hotel beds rose significantly and new tourism businesses such as, for example, rental apartments, were established as state-of-the-art in the Balearics. By then, the margins of the Centre had reached what the authorities perceived as the limit of deprivation and degradation. Several planning schemes were announced in order to "save" those neighbourhoods from neglect and vice. But only some of these schemes were ever set into action.

In the third boom phase (following the global crisis of 1991), "nature" and "culture" emerged as diversified tourism products and attractions, formerly limited to sun and beach. For Mallorca, this meant the commoditisation of the island's hinterland due to a growth in residential tourism (mostly related to the acquisition of second homes by wealthy locals and foreigners). Along with the projection of the hinterland's coastal and rural landscapes, the rundown Centre was promoted via a programme of "heritage revitalisation" while the renewal schemes remained in operation. During this period, there was a clear increase in the value of land and property prices all over Mallorca.

These different booms give a first insight into the tourism industry's regional development and its relation to the radical changes the different global economic crises have brought about. The analysis also reveals how the industry permeates most, if not all, economic policies of the Balearic Islands. Likewise, powerful lobbies like the hotel sector influence and design paths for urban development policy (Amer 2006). An example of how the third boom targeted "nature" and "culture" as tourism assets was the introduction of the so-called "Ecotax" in 2001 (Valdivielso 2001). This tax was charged on the accommodation rates paid by tourists and revenues had to be invested in both "green" products and culture-sensitive alternatives to the classical model of

7 Filtering refers to the process by which housing stock moves from higher-income to lower-income households as it ages and deteriorates. 
"beach" mass tourism. ${ }^{8}$ But the hotel federation's strong political influence aborted the experiment shortly after the tax was implemented.

Urban tourism is one of the legacies of the last boom's efforts to create "alternatives" to beach-based tourism. To make it work in Mallorca, the officials thought they needed to turn the whole of the Centre into an attraction by expanding commerce and catering, and particularly by creating or substantially altering the cultural and social environment of the monumental core. Indeed, tourism can be seen as the very reason why the Centre is a "Historic Centre", because its land and the activities that develop on it have been regulated around the heritage topic. ${ }^{9}$ Since the late 1980s, all public and private sector renewal initiatives have sought to bring the profitable tourism business to the Centre.

"Heritage" today is all over the place. It has expanded from the monumental core to the margins and in the process incorporated the more humble past of the Centre's craft businesses and industries and of the once striving working class they employed. As I want to show in the following section, this is only one side of the story: since the whole of the Centre has become the target of renewal and has been listed as a "must see"-attraction in all guidebooks, ${ }^{10}$ processes of gentrification have taken place in the areas that were once marginal and neglected. ${ }^{11}$ The promises of urban tourism serve as political arguments to renew the housing stock of the Centre by revaluing its heritageable items. Nevertheless, ever since their first implementation, these policies have been contested and appropriated by numerous groups, including the inhabitants of

8 The set strategy was not aiming at the substitution of mass tourism for a more "small-scale tourism" based on "nature" and "culture". Instead, tourism had to expand by incorporating new brands and models into the prevailing mass tourism industry (Morell 2000): e. g. natural parks had to be promoted as tourism attractions, cycling tours in the low season were to rocket, proposals for new interpretation centres mushroomed.

9 The monumental core of the Centre is mainly made up of historic monuments built by the religious, commercial and political forces still in control of Ciutat. The main sites are the gothic cathedral and the gothic foundational medieval parish churches, the medieval palaces of Muslim and Christian rulers facing the cathedral (nowadays the king's summer residence where official receptions are held), and the gothic building that housed the medieval merchants' guild. Minor sites of attraction are buildings now used as town hall, parliament, government offices, the headquarters of the Island Council of Mallorca, and several small palaces built by the nobility and the bourgeoisie. Furthermore there are the remains of the medieval ramparts on the waterfront and various museums and art galleries. The main commercial thoroughfares and boulevards join all of these sites. Most of the margins of the Centre are currently integrated into this monumental-shopping circuit.

10 E.g. <http://www.lonelyplanet.com/spain/mallorca> (last accessed 27/05/2009).

11 By gentrification I understand the displacement of low-income and working-class occupants because of the arrival of middle-class inhabitants to a neighbourhood (Glass 1964: xviii). This process changes the social character of the neighbourhood and at its core is "the complexity of capital mobility in and out of the built environment" (Smith 1996a: 51). For a comprehensive handbook on the history, discussions and the varied outcome of research on gentrification see Lees et al. (2008). 
the margins in what Franquesa and Morell (2005) have come to term "deviations to town-planning".

This section has retraced the economic and discursive construction of mass tourism and its supposedly small-scale alternatives from the 1960s to the early 2000s and has particularly focused on how it has influenced the Centre. Such "quality tourism", as opposed to mass tourism measured in "quantity", was targeted in several government agendas (e.g. the Ecotax and its heritage tourism projects). But it needs to be pointed out that this process is far more complex than the cliché of "quality small-scale tourism" proposals often included in the urban renewal schemes of the Centre would lead us to expect. Instead, as I will show in the following sections, these proposals offer an alibi for an indiscriminate large-scale "accumulation by dispossession” (Harvey 2003) via expropriations, rebuilding and real estate activities.

As the next section shows, the political and economic constraints of tourism are mediated via planning procedures that use the notion of fer barri. Whereas my reflections so far have been concerned with wider policies, I now turn to the different ways of fer barri and the power struggles at work on the neighbourhood scale. These struggles revolve around the history of the Centre's margins as a field for disinvestment and reinvestment and are based on the positioning of the Centre within a scalar hierarchy of tourism and the building and real estate opportunities that go along with it.

\section{PLANNING NEIGHBOURHOOD DISINVESTMENT AND REINVESTMENT}

The municipality of Ciutat $\left(213.56 \mathrm{~km}^{2}\right)$ has 413,781 inhabitants, of whom 25,579 live in the Centre $\left(1.24 \mathrm{~km}^{2}\right)$. But the Centre is much more than a residential area. It attracts numerous visitors each day since it hosts most of the administrative and institutional headquarters as well as the main shopping thoroughfares of the city. The Centre also serves as a collective memory"container" for the whole city because it is the main scene of public celebrations and citizen demands (often promoted as fent Ciutat). Furthermore, due to the added value of the heritage it contains, the Centre is exploited in terms both of the tourism industry and of related real estate activities.

Since its first amendment in 1964, the Centre's legal status as an Artistic and Heritage Area has been upheld by measures that promote its built environment, and especially the monumental core and the seafront. But all these measures have not given the Centre a uniform ambience. Whereas its core is the priority for protection and promotion, the areas in the margins were for many years not regarded as worthy of preservation. Here the built heritage of the guilds and the working class of Ciutat was and still is present. This legacy has only recently been integrated into the tourist and commercial routes of the 
Centre, but always in a partial manner and secluded in, for instance, interpretation centres. ${ }^{12}$

As early as the 1960s and 1970s the demographic features of the margins changed significantly. In earlier periods most of their inhabitants had moved en masse into the then new urban developments of Ciutat. Left behind was the elderly population living on low pensions. Due to the demographic changes and a lack of housing maintenance, land and property prices reached an all time low and those tenants who moved into the deserted flats had even fewer economic means than the working classes that had left the area. In the course of time, illicit economic and publicly censored activities (drug trade and prostitution) took root and spread. At the end of the 1970s, the authorities concluded that the margins were profoundly degraded. But instead of considering the overall changes in Ciutat and the lack of maintenance the owners professed, the authorities blamed the un-civic new inhabitants for the unhealthy housing-conditions (what the authorities viewed as unhealthy conditions) and declared this part of the Centre to be ruined. Consequently, the municipal authority's next step in urban planning policies aimed at an economic reactivation - a policy that was labelled "revitalisation via renewal". The main reason behind this policy was that these neighbourhoods were still close to the prospering Centre and some of the buildings were seen as marketable heritage attractions. Thus, in the 1980s, a series of urban renewal schemes cascaded down to the margins, targeting one neighbourhood at a time.

The neighbourhood we are dealing with here has as many different borders as names. For statistical purposes it is called El Sindicat $(3,848$ inhabitants, municipal census, $1^{\text {st }}$ January 2008) and for town planning purposes it is referred to as Sa Gerreria (The Pottery). As mentioned earlier, neighbours will generally refer to their neighbourhood as Es Barri, although the name of the association of neighbours is Canamunt. ${ }^{13}$ To complicate things further, most of the territory of Es Barri was once known as Barri Xino because of the

12 Interpretation centres are a kind of visitor centre/museum where one "interprets" a specific object or matter. For the case I am talking of here these centres usually involve the "interpretation" of the past.

13 In the $17^{\text {th }}$ Century, Ciutat, what we nowadays know as the Centre, was divided into two bandit territories, Canavall and Canamunt, respectively the lower and the upper parts of Ciutat. The area under study in this paper never had a specific name other than Barri Xino (red-light district) or the renewal scheme's name, Sa Gerreria. The association of neighbours established in 1991 - which I will talk about later - claimed almost half of what used to be Canamunt back in the $17^{\text {th }}$ century because there were no previous existing associations of neighbours in any of the territories the new Canamunt now held. The bordering neighbourhood of Sa Calatrava and other areas belonging to historic Canamunt were not included because associations were already active there (interview with a former head of the Federation of Associations of Neighbours of Ciutat, October 2008). 
illicit and/or censored activities it hosted. ${ }^{14}$ The press even nicknamed the area "Palma's Harlem" or "human dunghill" (El Día de Baleares, February 5th 1985 : 19-22). Furthermore, the group of streets where most of the aforementioned activities were concentrated was known as Es Brut (The Dirty Place). As several informants confirmed and as is well-documented in the local press, the $6^{\text {th }}$ Fleet of the American Navy patrolling the Mediterranean would regularly "find relief" there after months at sea. The novelist Frontera (1975) described the area in an underground tourist guide:

Es brut, the dirty place [...]. You will have noticed it by the smell. Old, ramshackle $[B]$ arrio $[C]$ hino. Incredible narrow streets, a labyrinth limited by [its] streets $[\ldots]:[\ldots]$ minute, gloomy, unrepeatable $[\ldots]$ with their women of all ages and appearances, sitting on the second step of the entrances through which one goes up to rooms with little red lights and the Virgin of Rocío and the Virgin of Macarena. With men as shadows, who go to the forbidden but tolerated market of the illegal traffic of corporal relief; with its unmistakable scent. The bars of these streets have music and television on and there are people who go up and people who come down: Occasional visitors and other addicts. This is the little island to which one comes deliberately: not one of its streets is on the way to the office. There is the "Club Salem" [...] for dancing and admiring the art of the ballerinas and vocalists. Out of the little island, the suburbs of the $[B]$ arrio $[C]$ hino, suburbs of a more ventilated kind: the streets that limit it, [...] with its "Hostal de la Bolla", the height of typicality [Frontera 1975: 77-78]. ${ }^{15}$

In 1989, the wave of renewal schemes of the 1980s finally targeted Es Barri. Aims were extreme and there were plans to turn the whole neighbourhood into Ciutat's new public administration headquarters along with newly created public spaces and a change in the rights-of-way. Even though the renewal scheme was regarded as necessary by many citizens, its extreme dimension was

14 The term actually means more than just "red-light district". It also incorporates outlaw activities such as drug dealing. The name was probably imported from Barcelona, where there also is a Barri Xino. Popular wisdom has it that the name came from the presence of Chinese or Philippine prostitutes. This is not true. Casasús (1996: 221) explains that Paco Madrid, a journalist writing for the weekly paper $E l$ Escándalo back in the 1920s, christened the southern tip of the $5^{\text {th }}$ District of Barcelona as Barri Xino. The area already was famous for its outlaw activities. The reasons for which he named it so are not at all clear. Some say it is because Madrid found Chinese imitation jewellery businesses there, others say that he had read the travel book written by Miguel Toledano who had been in the USA and spoke of San Francisco's China Town.

15 All quotes and interview excerpts originally in Catalan or Spanish are my own translation. Notice that I have previously used Barri Xino and that Frontera here uses Barrio Chino. Barri Xino is Catalan and Barrio Chino is Spanish. Although Frontera is well-known for his novels in Catalan he wrote this guide in Spanish. 
soon opposed widely. ARCA (Association for the Revitalisation of Old Towns), founded in 1987, and the association of neighbours of Canamunt (from now on Canamunt), created in 1991 by the Federation of Associations of Neighbours in Ciutat, ${ }^{16}$ took the lead in this oppositional movement - though with different aims. Canamunt insisted on the continuation of predominantly residential use and demanded that the already settled population should be given support with services for the neighbourhood and not for the whole city. ARCA maintained that buildings could not be bulldozed as the historical street alignments and the old industrial buildings formed part of the heritage of Ciutat.

The political leadership in the Town Council changed in 1991 and the implementation of the renewal scheme came to a halt. But a revision of the 1989 planning scheme was approved in 1995 when the new town-council board reached a consensus with Canamunt and ARCA. Now the aim was to recover the social fabric and the existing buildings as well as to preserve the historic urban structure. This had to include support for the present inhabitants and the implementation of development schemes for the neighbourhood. As I will show in the following section, the real aim was to revalue the neighbourhood by gentrifying it and making it amenable for tourists.

Part of this contradiction between words and facts was the transfer of these genuinely public affairs to the private sector. The management of the Sa Gerreria renewal scheme under public-private partnership broke with the model employed in all previous schemes. Private sector companies were responsible for evaluating all properties acquired by compulsory purchase. None of the residents had a say in these purchases and many buildings were pulled down as the private company promoted the construction, sale and lease of new dwellings. The public agencies followed an agenda to "improve" the image of the neighbourhood in order to achieve a favourable atmosphere for private investment.

Local and regional governments in Mallorca had received political and financial support from the Spanish State and the EU to improve and build up major urban infrastructure in the area. The State financed new courts for the whole city. With EU funding under the URBAN 1994-1999 Programme, facilities for neighbourhood use as well as aid and training schemes for the impoverished and "needy" population were provided. ${ }^{17}$ These projects improved the

16 This proceeding was very unusual. Normally the associations of neighbours are created by neighbours already living in an area and then, if they wish, they become a federated association of the Federation. The case of Canamunt is different since it was the Federation that founded Canamunt.

17 The aim of the URBAN programme is to revitalise degraded urban areas. In 1997, a total sum of $€ 15,260,000$ was granted for the revitalisation of the URBAN area of Ciutat of which half came from European Regional Development Funds and European Structural Funds and half from the local and regional authorities (<ec.europa.eu/regional_policy/urban2/urban/initiative/src/frame2.htm>, last accessed 11/08/2009). 
environment sufficiently to sustain the expectation of future private sector investment and thus helped to reaffirm the promise that the margins of the Centre could be recovered for Ciutat, underwriting a very partial image of who held the right to the city. In this atmosphere of hope, the city authorities promoted a return of the population to the neighbourhood as if it had been an empty space up to now. Urban tourism and heritage were portrayed as the means to solve all problems. The EU URBAN programme was presented as the culmination of long-lasting efforts to "recover" the Centre (Ajuntament de Palma 1999). ${ }^{18}$ The local councillor for tourism set out the aims of the project in its early days at a conference that dealt with urban renewal in the Historic Centre of Ciutat:

We have to boost this historic centre to its full capacity. We understand that it is not easy to maintain a neighbourhood, its streets, a historic centre, if we do not bring life into it, if we are not capable of attracting people - the citizens who buy houses, flats - and some kind of economic activity to it, that is, light, warmth, people: This is what can really raise a historic centre. Indeed, it has cost a lot, but I think that there is recent major real estate investment, and, unfortunately, we have to confess that most of them are European citizens who understand the high quality of life they have due to living so near to the sea and in such an important historic centre [Juan Bauzá in Baltasar et al. 1995: 94, emphasis mine].

The local councillor for tourism did not only aptly summarise the notion of an empty space created to justify the massive evictions of Es Barri's inhabitants. He also indicated that the desired new residents were not necessarily locals but wealthy citizens of other European countries wishing to buy a second property in a built environment close to the sea and permeated with history. But to my knowledge, "Europeans" (stated above as if Mallorcans were from another continent) have never shown an interest in acquiring real state in the Centre, let alone in Es Barri. Of course, there are the odd foreign residents here and there but by no means do they represent the leading trend the local councillor for tourism desired.

From what has been said, one can argue that the scale of the neighbourhood is, in part, the product of a municipal urban policy that formally sought to balance living conditions in all neighbourhoods through the distribution of welfare and wealth based on territorial classifications (as argued by Ruiz Viñals

18 Although this does not mean that the Spanish state and the EU forced the local authorities to gentrify the neighbourhood it does signal that there was, and still is, a multi-scalar commitment for urban renewal and the gentrification that often comes along with it. For instance, it is noticeable that gentrification (e.g. how to avoid it) is almost nonexistent in the URBAN Programme documents offered on their official websites. 
2000: 240) rather than social ones. ${ }^{19}$ Another proof for this observation was that incentive-generating renewal schemes were implemented nowhere else but at the margins of the Centre. But not all renewal schemes followed the same logic. In the early 1980s the first renewal scheme, that of the Puig de Sant Pere, located in the southwestern corner of the Centre, included policies aiming to keep the demographic composition stable. Contrary to this first renewal experience, inhabitants of Es Barri were ousted in the late 1990s with the implementation of a clear municipal-led strategy of gentrification based on the logic of a "social mix" evident in the "Report of the General Scheme for Urban Planning (Memòria del PGOU)":

Intervention based solely on social housing in a deteriorated medieval heritage site can be as wrong as a façade project [...]. A comprehensive regeneration and requalification of the city can only be achieved by an intervention that combines and balances both strategies. There is another important omission in the texts of the renewal schemes: that regarding the promotional measures to be taken for the installation of mid-high strata population, who together with the already housed social population, produce the mix the Historic Centre once enjoyed, one that made it socially alive. The rules the renewal schemes contained [...] did not hinder from realising [the achievement of] this population integration since, except for the aim of maintaining the rooted population in the neighbourhood, it does not exclude other kinds of population [Ajuntament de Palma 1998: 80].

Thus, the "territorial distribution" actually consisted in "mixing" wealthy local middle-class newcomers with the poorer inhabitants already established, so as to "positively stimulate" the environment, in an entrepreneurial fashion rather than a redistributive one (Franquesa 2007). Such "mixing" strategy has almost ended up with a de facto substitution of the poorer population.

Of the six building projects that URBAN financed in Es Barri, one was chosen to imbue the neighbourhood with a new touristy atmosphere: the Passeig per l'Artesania (Crafts' Walk, from now on P'A). This new attraction was supposed to benefit from the history of the neighbourhood that should attract visitors and support local businesses. Furthermore, it should also convey that real estate was a secure investment. As the following story of the evolution of the P'A will show, those elements that had initially been intended to improve the neighbourhood, to fer barri, ended up becoming a project to fer ciutat.

19 Attracting affluent owners (be they "European" or not) was in its own right a siren song for "socially mixing" the population. Also this mix was only intended for the renewed neighbourhoods, but not for the whole of Ciutat. Thus, only certain territories were promoted for the distribution of either welfare or wealth without regard to the social and economic conditions of many other people across the city. 
From the very beginning, the P'A was conceived of as a space to develop local commerce. The idea was to offer premises to craftspeople through a public tendering procedure (theoretically below market price). Those with an interest had to present both a craft production and a business plan. If selected, the local craftspeople had to make an initial investment to establish the business they would run on the premises. After four years of construction works and preparations, the P'A was launched in 2001. Initially 15 workshop businesses settled in, but soon the craftspeople abandoned the site because of the little business they could make. A local newspaper headlined: "One of them leaves after losing more than the $€ 42,000$ she invested - She claims that only distributors remain in the P'A" (El Mundo-El Día de Baleares, December 17 $\left.7^{\text {th }}, 2002\right)$.

According to the head of the P'A development, problems occurred because the P'A was an isolated space in the middle of a neighbourhood in the making. And this neighbourhood was still carrying the stigma of the old red-light district, Es Barri Xino. Moreover, it was argued that the products were not attractive enough to pull in either tourists or locals as customers and that the craftspeople were lacking a clear marketing strategy. They were accused of waiting for the clientele to turn up "naturally" or to be brought to them "artificially" by the municipal authorities. In fact some craftspeople opposed the idea of turning their work into a tourist attraction. This is illustrated by the following statement of a middle-aged book-binder running a business close to the P'A (although not belonging to the P'A project) who had initially supported the idea of a crafts" cluster: "They would actually like us to be like in a cage at the zoo, with people taking pictures of us, but I'm not going to be performing the monkey role for them, you can be sure about that!" (personal interview, November 2006).

In the very same year that I collected this harsh statement the town council counter-attacked by establishing new admission conditions, by awarding new contracts and by modernising the corporate image of the P'A and the new businesses. Documentation and interpretation centres were provided in the P'A and a historical walk was designed, guiding tourists around the places where disappeared trades were carried out and telling the story of its past as a centre of craftsmanship. In tune with this philosophy, the P'A was turned into a public venue for music performances in the summer. But all these efforts were not enough and the P'A was completely empty when I visited it in the past years.

To sum up, the major role intended for the P'A was to create a commercial link between tourism and the industrial past of Es Barri. Even though this role did not meet all the aims established in the urban development plan, the PGOU, and within the renewal scheme of Sa Gerreria, the P'A did work as it offered a pleasant atmosphere and the promise of a revitalisation of the neighbourhood. As a publicly funded initiative, the P'A in the end helped to attract people who invested in Es Barri and bought up renovated or newly built properties, set 
into value by the private companies in charge of the money-generating side of the redevelopment scheme. Thus, the P'A can be seen as a "crafted illusion" of the neighbourhood's past, placing it on a map for investors but not for tourists - a map financed by the EU, the Spanish State and various regional and local governing bodies. This last summer of 2009 the P'A came to an end. The area is now aimed to host a creative cluster for "entrepreneurial businesses".

In this section, I have analysed the urban renewal scheme of Sa Gerreria. My focus was on the unequal division of power established via the revitalisation and investment schemes and on urban development policies involving administration and financial support on different scales: the municipality, the island council, the regional authorities, the Spanish State and the EU. But the scaling of the neighbourhood goes beyond the sum of urban development policies and economic constraints. A large part of it is made up of how the inhabitants perceive and organise the neighbourhood scale. The following sections show that the neighbourhood is not at all unanimous but contains diverse people from various social backgrounds. Along these social divisions or crosscutting them, internal differences within the neighbourhood are established and lived and these need to be considered too. I will therefore compare two different ways in which the inhabitants of Es Barri engage with fer barri. The first is established by Canamunt and is concerned with the "centralisation" of the neighbourhood, that is, the process by which the neighbourhood has to attract visitors as the rest of the Centre does. Whereas the new leaders of Canamunt want to "centralise" Es Barri via the rescaling of its neighbourhood festes, the second analysis is one of a vanishing concept of fer barri, the weakening of neighbourly relations in Ca na Pepa, the local grocery described in the introduction to this paper.

\section{THE ASSOCIATION AND THE FESTES}

Canamunt had built its efforts to alter the course of urban renewal in Ciutat on gaining the support of the inhabitants most affected by gentrification. In Es Barri, Canamunt had tried to find the approval of lifelong residents, different waves of gentrifying newcomers and, to a certain extent, the ever present marginalised groups involved in drug trafficking and prostitution. Despite its efforts, its strength diminished after 1995. More generally speaking, actions had been restricted to two different periods: 1989-1997 and 2002-2004. Most efforts had been put into the reactivation of neighbourhood festes in order to enhance approval and support for the struggle against the municipal-led renewal schemes of Sa Gerreria and El Temple. ${ }^{20}$ Oppositional

20 El Temple is the largest single block of buildings in the Centre, located on the southern tip of the Canamunt territory. 
strategies had included media campaigns aimed at creating awareness of the excesses of the renewal scheme by denouncing evictions, the destruction of built heritage and the abandonment of previous neighbourhood lifestyles as well as the centre-oriented urban planning of the town council. But these had been sidelined by a strategy of getting closer to the decision-making bodies in order to lighten the immediate effects of the renewal scheme on the neighbourhood. This second strategy had proven so "successful" that Canamunt activities were soon reduced to mere whistle-blowing on the public administration's policies while actually collaborating by way of rephrasing the renewal scheme of Sa Gerreria insisting on actual implementations of the social and heritage issues. ${ }^{21}$

Instead, events followed the agenda set by the PGOU, meaning the eviction of long time inhabitants to accomplish the "necessary social mix" and the bulldozing of most lower-class housing. The actual built heritage of Es Barri gave way to "proper" facades. When the now public-private-civilian partnership reformulated the renewal scheme in 1995 and the amendments were approved by the town council, Canamunt almost disappeared. ${ }^{22}$ Although activities flashed up now and again, Canamunt never managed to get a new generation of activists on board who would take over and revive the leadership. Efforts to fer barri the Canamunt way - meaning to establish links between the household sphere and the public sphere in the neighbourhood - also ceased.

On the $27^{\text {th }}$ of September 2007 though, hopes were high that Canamunt would come back to life again. A room in the Centre Social Flassaders, the second largest project built under the URBAN funding initiative, had been made available for a Canamunt "revitalisation" meeting. ${ }^{23}$ More than fifty people had gathered to discuss problems of the neighbourhood and it very much looked as if this was the resurrection many old members of the board had hoped for. ${ }^{24}$ Due to the unusually high attendance the small room was packed. Most newcomers were actually new residents: entrepreneurs of the arts,

21 This rephrasing was mainly based on the conclusions of a social and demographic survey of the neighbourhood Canamunt carried out by order of the town council (Associació de Veïnats de Canamunt 1993). The survey aimed to detect the social needs of the inhabitants. One conclusion was that the population should be maintained, but as has already been indicated, this actually did not happen. Canamunt's efforts to conserve all heritage sites in Es Barri were soon limited to defending a few salient buildings. According to my observations, reasons for the opposition's decline were that most activists got worn out and preferred to get on with their own individual life and projects.

22 In the following years, the renewal scheme was subject to consecutive amendments that bypassed the earlier rephrasing of the scheme that had emphasized the maintenance of the original population and the conservation of heritage.

23 The largest project both in size and in costs was the Passeig per l'Artesania (P'A), discussed earlier.

24 Most of these older members worked as civil servants or held liberal professions and moved in during the late 1980s. 
businesspeople such as bar owners and people with university degrees. Most of them lived in the revamped properties of the renewal scheme. Shopkeepers who had managed to survive the time of Es Brut and its regeneration sat side by side with the owners of the mushrooming neo-bohemian shops and bars in free-and-easy aesthetic style. ${ }^{25}$ The members of the Canamunt board were happy to have managed to attract such a variety of people only by word of mouth and by putting up posters. But as the meeting progressed, their greatest delight, the fact that more than half of the attendants were "new neighbours", turned out to invite unexpected and enduring troubles.

The original agenda of the meeting had listed four topics of central concern to the old members. These were: (a) to pedestrianise certain streets; (b) to discuss the use of publicly owned properties catalogued as heritage; (c) to comment on the increasing number of late night bars; and (d) to reinstate the Canamunt festes. ${ }^{26}$ But little was said on these matters because a good deal of those present, especially the new neighbours, moved another issue to the top of the agenda - to elect a new board. And so it happened. A couple of weeks later, a new board of three was installed and among them only the spokesman was a long-term member of Canamunt. Although this was never verbalised openly, the following events showed that the new neighbours who took over Canamunt had a very clear agenda. In a meeting held some months after the changes in board membership, the owner of a state-of-the-art restaurant demanded that one of Canamunt's policies should be to ask the town council to bring in more tourists so that Es Barri would "truly become part of the Centre". Thus, the now active members of Canamunt who owned bars and restaurants wanted to fer barri for the sake of their own businesses.

The revival of Canamunt turned into one of the major ironies of Es Barri's recent history. To ban cars from the quarter's streets or to discuss the uses of publicly owned heritage sites never became central issues. Neither was the increase in bars commented upon critically. Instead, Canamunt was transformed into a vessel supporting at least some of the bars in the area by involving them in the organisation of its festes and thus, as some old members would argue, threatening to transform the neighbourhood into a bar zone. Municipal ordinances only allow associations of neighbours to organise public celebrations in the neighbourhoods. Thus, as an association of neighbours Canamunt acquired the official sanction to hold annual festes in the neighbourhood and these festes were the one further incentive for the newcomers owning bars to

25 For a particular account on the working of neo-bohemia in Chicago's Wicker Park neighbourhood see Lloyd (2006).

26 A fifth topic was the need to reorganise the association before more than 300 new flats, built in a kitsch "Mediterranean style" where Es Brut once stood, were sold. This was often referred to as "ground zero" because of the full demolition that took place there. However, this was not an "official bullet point" on the agenda. 
take control if not of the association as a whole, then at least of the possibility to organise the festes under the umbrella of the association.

Since 2005, one of the most fashionable bars in the neighbourhood had organised anniversary celebrations which had been highly successful. These celebrations received public support from Canamunt in 2007 and in 2008 the association decided to turn the bar's party into the neighbourhood festes. This meant that the festes from then on were represented legally by Canamunt and that the organising committee had the right to ask local authorities for permission to hold concerts and other shows in the squares of the neighbourhood. The committee could even demand closure to traffic, something bars cannot do. Canamunt should benefit from showing its new strength to the local authorities and take control of the threat of a bar expansion or, as someone put it, of Es Bar/ri. By allying with the bars already established in the area, the old members of Canamunt wanted to defend the territory against the opening of further bars, thus defending the business rights of the new members in a very protectionist manner.

The first festes of this new alliance were held in July 2008 and lasted for several days. On the night of the main event, a queer music show, the squares of the neighbourhood were packed and it was difficult to move through the crowd of mainly young people who had come from all over the city to enjoy the show. On stage, several drag queens and transvestite artists from Madrid who had been hired by "La Terremoto", the female co-owner of the pioneering fashion bar celebrating its anniversary, ${ }^{27}$ were lip-synching to songs of the 1980s, the golden age of Spanish pop referred to as La Movida. The event was the largest concentration of people the neighbourhood had ever seen - unmatched even in the days when the $6^{\text {th }}$ fleet regularly came to visit. Queues for getting to the drink posts, where ironically old and new members of Canamunt worked side by side the whole night through, were long. In the dark back streets surrounding the square where the main event was held, people urinated and dropped huge amounts of litter. The few policemen present wore desperate looks on their faces as they felt unable to stop such a huge crowd from partying way beyond the official decibel limits.

A week later, at a meeting of Canamunt, the owners of the organising bar calculated that more than 3,000 people had attended. At first, the new board members thought the festes had been a massive success. But they soon realised that the event had gone beyond reasonable limits. The board decided to reflect upon this when planning future events and it seemed as if future festes would be downsized. Nevertheless, the festa planned for July 2009 has been of such

27 "La Terremoto" literally translates into "The Earthquake". Not only is "La Terremoto" the co-owner of the pioneering fashion bar but she is also a show-business woman well-known for her appearances on Spanish national TV reality shows. 
a dimension that it has escalated beyond the neighbourhood. Canamunt went into negotiations with the association of neighbours of the neighbouring quarter Sa Calatrava. When the two associations of neighbours joined to hold a festa in the park beneath the ramparts of Sa Calatrava, they did not only aim for a show far bigger than the previous one. Their joint venture also brought the URBAN project full circle to some degree as the territories of the renewal schemes of Sa Gerreria and Sa Calatrava exactly match the boundaries of the EU funded project. The 2009 festa was again run by the owners of the pioneering bar and again coincided with the bar's opening anniversary.

Not everybody was happy with these developments. Some bar owners oppose them not so much because only one bar is organising and thus promoted via the festes, but because they no longer benefit from selling drinks and food to the crowds who now gather outside the neighbourhood boundaries. Other neighbours have argued that these are neither festes "of the neighbourhood" nor festes "for the neighbourhood". In fact, not all of the new members of Canamunt belong to the business crowd. An archaeologist renowned for his adamant defence of the whole Centre as heritage, and now the head of the Heritage Department of the Town Council, said not long after the event of 2008: "These festes have been festes for the whole of Ciutat [and not for the neighbourhood] and they have nothing to do with those of the neighbourhood which took place in the 1950s" (conversation, August 2008).

The course of events in Es Barri and the significant changes in the nature of the festes moves discussions of so-called grassroots organisations to another level. A neighbourhood festa organised by people initially committed to saving the neighbourhood from the downsides of gentrification is obviously something very different than a festa organised by a local bar celebrating its opening anniversary. The changing nature and the change in purpose of the event challenge the assumption that scales are ideal static encapsulations of social realities. The events in Es Barri show how economic and political forces condition neighbourhood relations and underline the role tourism plays in Mallorca. Furthermore, the case of the festes signals the existence of "jumping scales" (Smith 1996b) but also shows that the neighbourhood scale is not confined to relations and forces beyond its spatial limits. The scale of the neighbourhood is defined by networks based on economic and political powers in Ciutat and with nationwide reach. Changing Canamunt into an association that supports the bar owners' lobbying organisation has not only been mutually beneficial for the different parties involved but has also led to the "rescaling" (Uitermark 2002) of an event, moving from a single bar enterprise to Canamunt and then beyond the neighbourhood itself. The last step, a very vivid example of "jumping scales", resulted in the whole city paying attention to the joint team now organising the festes and thus coalescing different institutions and organisations working on the neighbourhood scale beyond the neighbourhood. 
This section of the paper has been concerned with the changing uses of the neighbourhood scale on the level of a so-called grassroots organisation. Besides the issue of who has the power to organise festes, there is now at least one further contentious dimension of the neighbourhood scale to be explored in more detail. This question goes down to the very basic level of who has the right to live in the neighbourhood and decide on the workings of its social structures and who does not. In order to analyse this dimension, the next section is concerned with the people gathering in the grocery already introduced at the beginning of this paper, their ideas of fer barri and the days when Canamunt was not busy jumping scales to boost the festes but busy jumping scales in dealing with the rights of the inhabitants of Es Barri themselves.

\section{A NEIGHBOURHOOD IN THE GROCERY}

The social relations that make up the neighbourhood are composed of and negotiated within a number of settings of which the association of neighbours is only one. These associations were formed to democratise public life during the twilight of Franco's dictatorship in the 1970s. Because they only serve to organise the neighbourhoods around particular issues, important relations among neighbours remain outside of their organisational frame. Whereas one could argue that the business concerns of the bars explained above should remain outside this category, the fact that the owners of the trendy bars also inhabit the area means that they have a certain entitlement to their cause. But even at the level of bars and businesses, there are other interests. Many bars in Es Barri close before the nightlife starts. These are called bars de dia (day bars) and they serve as meeting places for many residents, businessmen and passers-by.

Similar to the bars de dia, other businesses have existed long before gentrification in the quarter started and these also rely on similar neighbourhood networks. In recent years most of these businesses have closed down because of the changes coming along with the renewal and gentrification processes. Unlike the associations of neighbours, the social networks formed around these businesses have never been directly involved with the public administration. In the following section I return to Ca na Pepa, one of the last groceries in Es Barri, and explore how the shop's long-term clients relate to the institutional and organisational changes in the neighbourhood.

People gather in Ca na Pepa for two central purposes: they either follow the genuine need to buy food or they seek neighbourliness, often to combat boredom. Furthermore, most of them claim that what is left of the neighbourhood, left of fer barri, does only exist in this grocery or, at the most, in its immediate surroundings. The majority of customers are the elderly inhabitants of nearby buildings who pay rents that are not rated by the market but by old ownership 
and tenement laws, with fixed established prices. Also, there are youths who meet in the street to while away their time or to sell drugs. Because all other businesses of the same kind as Pepa's have closed down in Es Barri, the grocery's survival deserves explanation. Unlike other old businesses in the area, Ca na Pepa can count on the fidelity of two groups of clients, the remaining immediate neighbours and many of those who have left deliberately or were evicted by real estate businesses but who still come back to shop and chat to their old neighbours and to Pepa.

All the people meeting in Ca na Pepa share an understanding of what neighbourliness and fer barri means. To them it is an increasingly scarce resource among the shrinking population of "old neighbours". ${ }^{28}$ The dimension of the neighbourhood scale constituted by them is about trust and mutual aid something I call neighbourliness. Gossiping, for instance, plays an important role since it is an activity that transmits ideas, glues coalitions and dissolves tensions. Gossiping also serves as a means of social control because a pool of information is created and centralised in the grocery and therefore Pepa holds a prominent role. Whereas everyone meeting in her shop has in one way or another access to this information, she knows how to exploit the pool for her own benefit. Gossip is a way to fer barri too because this way alliances that help to sweeten sour experiences and mellow eviction are created and forged. At the most, for those who are not familiar with the rapid changes in Es Barri's property market, gossip can be a decisive tool to get an idea of the value of housing and, as we will see, can forge alliances to reach agreements with developers and to avoid forcible evictions. ${ }^{29}$

In August 2008, while everyone was still recovering from the Canamunt festes, Pepa closed down her "official grocery". ${ }^{30}$ Her main clients, who used to live in the same building, had been leaving their flats one by one. They had reached individual agreements with the new owner in order to avoid

28 On the one hand, one might argue that for the case of Ca na Pepa, the illusion of smallness has to do with the attachment to the place Pepa and her client-friends seem to profess. On the other, there is clearly a constraint to the kind of activities impoverished elderly people such as the women referred to in the introduction can actually afford. Rather than a case of place attachment, what we are here dealing with is people trapped in place (Franquesa 2005), irrespective of whether they celebrate their attachment or because their way to fer barri is all they know and all they can know.

29 Through gossiping bits of information are collected here and there. The information travels to the ones interested in knowing, be they in Ca na Pepa or elsewhere. Developers even send "information collectors" to places like the grocery in order to fork out this kind of information without having to make their intentions official by visiting the property registry. It is often a first step before actually going to the registry office as it helps the developers to find out who the tenants are. Developers will have to compensate tenants if a deal with the owner is reached (interview with a young "information collector", November 2006).

30 Since Pepa only held the business rights for which the contract was expiring soon and did not own the property, she could do nothing to stay longer in the premises. The most she could hope for was to get a financial compensation from the building's new owner for ceding her rights. 
eviction. But behind these agreements had been Pepa who had promoted the organisation of her neighbours in a covert manner. To support their cause, she worked through the established neighbourly relations and once she had gathered enough support from the people affected, she went to see a young lawyer, whose father had owned one of the largest houses in the area but had left long before the degradation period in the late 1970s and the 1980s. The lawyer negotiated with the real estate company in the name of all neighbours affected, but did not approach the solution to their case as a collective. He and Pepa worked for the benefit of those who had written contracts and he told me that he had not charged anyone for his services because he wanted to help the Ca na Pepa people. ${ }^{31}$ Pepa was compensated for the transfer of her business with a very generous deal. She then moved into the empty basement of her father's property opposite to her previous business in order to sell her remaining goods.

But in the course of the negotiations, the developer rejected the claims of all those residents who had only verbal contracts for their flats. When all these claims were dismissed, Pepa stood up for them and insisted that the developer had to reach an agreement. In order to make this happen she decided to take action on her own terms and apply her idea of fer barri beyond the neighbourhood. She flagged up the situation of her neighbours in the press using contacts she had made years ago, when journalists were writing about the changes in the area and had approached her as one of the remaining "neighbourhood businesses". When the case appeared in the press and even on local TV, the developer softened his position and reached a deal with the remaining tenants.

The fact that the developer backed down is by no means surprising. But the politics of Canamunt in relation to this dispute deserve attention. Only after the news appeared in the media did Canamunt pay any attention to the threat of eviction the Ca na Pepa people were facing. As I will now show, this neglect was grounded in a particular idea the present day decision-makers within Canamunt have of Pepa and her clients. This idea is the most recent development within a history of interaction between these two groups and says a lot about the historical changes in Canamunt's policy towards and understanding of fer barri.

The history of interaction between the "Ca na Pepa neighbourhood" and Canamunt dates back to the early days of resistance against urban renewal. Following instructions of the then highly centralised Federation of Associations of Neighbours in Ciutat, some of its members moved to Es Barri in the late 1980s and founded Canamunt, becoming part of a first wave of gentrifiers. Their intention was to engage in fer barri by forging an opposition to the renewal scheme together with long-term inhabitants like those to be found 
in Ca na Pepa. Among these newcomers was Isa, at the time a young activist and theatre actress who came to the neighbourhood not only because of the strategy set forward by the Federation but also because of the low rental prices, neo-bohemian atmosphere, the urban heritage and her commitment to defend the interests of the lower classes. Isa sought contacts with the "rooted" population through the people who ran those businesses that had resisted the process of degradation back in the mid-1980s before the implementation of the renewal scheme of Sa Gerreria.

The idea of the Federation was that by combining the social networks of the long-time residents and their philosophy of grassroots action, the neighbourhood would become a stronghold against the policies of the city administration. What the activists were well aware of and tried to take advantage of was that businesses such as Pepa's were not only neighbourhood businesses but also the "businesses that made the neighbourhood" through their everyday practices. As Isa recalls:

These businesses, like that of Pepa's, are something difficult to find elsewhere in the city, they are like humble social clubs, if you know what I mean. I feel they represent what the neighbourhood used to look like before. You know, places where you take a seat, where there's no rush and one gets to know the ins and outs of the neighbourhood. When I arrived [in Es Barri] I used to shop there a lot just for the sake of getting to know what the concerns of these people were. To get to know them [...] and, of course, for them to get to know us [conversation, May 2008].

The Federation had a clear strategy consisting in invoking the collective memory of Es Barri: the activists addressed the shared social practices of residential communities, their place attachment and their way of fer barri. Groups of people like those gathering around $\mathrm{Ca}$ na Pepa were, according to the Federation strategy, the bearers of neighbourhood values. To establish relationships of mutual trust and to form alliances, Isa needed to network herself into the close-knit group of the Ca na Pepa people. Many of them hesitated to join a politicised movement, as the Federation back then claimed to be further to the left than the official left wing parties. Furthermore, they were not very sure of the name and the spatial extension of the neighbourhood the activists claimed when they chose to refer to the $17^{\text {th }}$ century division into bandit territories of what today is the Centre. But on the other hand, the Ca na Pepa people preferred the action of the activist newcomers to those of the bulldozers that made room for the P'A. As they saw this area separating from what they called Es Barri and losing its neighbourliness, Canamunt became an appropriate means to either keep their right to the neighbourhood or gain compensation for eviction from their flats. 
Soon after Canamunt was established in the neighbourhood in the early 1990s, people such as those of Ca na Pepa took over the leading role in the festes revival. Their involvement soon became the legitimating element for Canamunt. But with the latest changes in the Canamunt board, the association of neighbours slowly relegated the $C a$ na Pepa people to a folkloristic role to the extent that in the preparatory meetings for the Canamunt festes of 2008, the owner of the thriving bar, the TV star "La Terremoto", suggested that since Pepa was a "rooted institution" of the neighbourhood, she could read the opening address to the public. It is difficult to say whether "La Terremoto" actually had the struggle of the Ca na Pepa people with the developer in mind and meant to support them - she never mentioned anything like that. Pepa's presence would have given a "neighbourhood touch" to the event, but to suggest she held a key role in the festes was also an act of positive discrimination as it unfortunately appeared at a moment when the people of Ca na Pepa were becoming part of the history of Es Barri.

This is another incident where the social constructions of scale meet social practice and where scale is influenced by all factors outlined in the analytical section of my introduction. Scale is socially constructed (Marston 2000), made real within processes of power struggles (Howitt 2000), an interaction of forces active on different positions in the scalar hierarchy (Brenner 2001) but, most of all, scale determines its own social context (Manson 2008). Thus, the distinctions between these authors' notions disintegrate and we find all of these meanings of scale in place when they are applied thoroughly to a social setting in a time of rapid change like Es Barri. For many of the newcomers, $C a$ na Pepa and the neighbours that turn this business into a social setting where the neighbourhood is made were an expression of typicality precisely because this way of fer barri is nearing extinction. "La Terremoto" seemed to be more interested in including Pepa in her festes show repertoire than to work out how to avoid her eviction. Back in the late 1980s and early 1990s the Federation instead perceived the same group as neighbours in need but also as the ideal group whose participation would have a legitimising role in the fight against the future waves of gentrification.

It seems that these two different waves of gentrifiers, the activists and the new bohemians belonging to Canamunt, in different periods of rapid social change felt the need to integrate Ca na Pepa into their own ideas of fer barri. The long-term residents gathering in Ca na Pepa have managed to be compensated for having to leave because the rights they held to the flats in the decaying buildings were acknowledged after all. This by no means signifies that there is no harm to them because of the renewal process. Instead, with the disappearance of the spaces that facilitated these practices and ideas of scale, a particular way of fer barri, the one practised at Ca na Pepa, is vanishing in Es Barri. 


\section{CONCLUSION}

In my introduction I referred to a remark by Ulf Hannerz on the imaginations and idealisations of smallness. The case of Es Barri has shown that the grass might actually not always be greener on the other side of the fence. This neighbourhood in the capital city of Mallorca has not only been generated by its own means but most of all by larger political and economic contexts that shape the social relations that constitute the neighbourhood from within. To follow the integrative and "jumping scales" approach chosen in this paper opens up the possibility to analyse the material manifestations emerging from the illusions triggered by imaginations of the neighbourhood scale. Along these lines, notions of the local practice of fer barri work as catalysts for contested projects in which power dimensions intervene and (re-)scale the neighbourhood according to economic and political purposes.

The escalation of the festa of Canamunt I have described is just one of the many manifestations of neighbourhood rescaling. Similar processes of "festa escalation" have been explored elsewhere. The prolific work of Boissevain on Maltese festi (e.g. 1984, 1992) shows that "festa escalation" is not only about merely increasing money spending and revenue but actually also involves re-establishing identity and reaching a peace of communitas. Something noticeable in the alliance the old members of Canamunt seek with the new ones. Nevertheless, the escalation of festes in Es Barri also involves a good deal of conflict and therefore serves to explore the power dimensions that make the neighbourhood. As the example of Ciutat shows, these power dimensions are not solely structural ones.

Scott has argued, that "strong neighbourhoods, like strong cities, are the product of complex processes that cannot be replicated from above" (Scott 1998: 144). While it might be true that these processes cannot be replicated from above, the power of official and private sector development agencies to confer or destroy the uniqueness of Ciutat's neighbourhoods is present everywhere. The uniqueness of neighbourhoods emerges on lower absolute scales and can be both adaptations to renewal and initiatives to further renewal. This has been shown in the case of the Ca na Pepa people who try to get away with the best deal possible and in the strategic take-over of Canamunt by bar owners who seek to enhance their profits. Of further significance is the delicate relation between renewal and gentrification on the one hand and efforts to preserve the neighbourhood's uniqueness on the other hand. ${ }^{32}$

32 From a planning point of view, uniqueness is desirable but almost unachievable. The new apartments built where Es Brut once stood were presented as a unique and differentiated product. Nevertheless, the site resembles more than anything the new "Mediterranean style" apartment common to the coasts of Southern Europe. 
Tourism, real estate markets and the renewal schemes for Es Barri have led to the decline and finally to the "neo-bohemian entrepreneurialisation" of the neighbours' movement. In the course of these changes, Canamunt's guiding and founding principle, the "social justice" agenda, has been abandoned and the interpretation of what is heritage has changed significantly in the process of revaluing the neighbourhood. As seen above, the tourism industry has actually encountered difficulties to establish its presence in Es Barri. Unlike other parts of the Centre, Es Barri has no tourists. The most salient feature of the tourism industry in Es Barri is that it mainly existed in the hopes and plans of those authorities responsible for the P'A - if not for the real money then at least for the promise held by an emerging myth of heritage tourism as a cash cow.

To some extent this idea is shared by those bar owners who try to attract customers - no matter if the customers are tourists or not. As a matter of fact, tourism is both a justifying myth and a market factor for real estate investment but definitely not an actual presence in terms of real people. This might explain why there has always been a lack of opposition to touristification in Es Barri.

Seen from another angle, the different institutions and associations that have been engaged in shaping the neighbourhood since the mid-1980s have each needed to create an image of scale, an "illusion", either as a means of exclusion from the rest of the urban fabric (e.g. Es Brut) or as a way to promote the neighbourhood as a tourism space (e.g. Historic Centre). The economic rationale behind these scalar illusions has been synthesised in the implementation of a succession of renewal schemes. The commoditisation of the neighbourhood as a marketable social setting has been built on a sense of place attachment and neighbourliness that has actually been destroyed by the entrepreneurial turn within the association of neighbours. This turn signalled the end of a whole community of neighbours that had believed and invested into building social relations because of their attachment to "their" practices. In short, to a certain extent the Ca na Pepa people may have been suitable for the scale-making project to fer barri in the pre-gentrified neighbourhood but they are not suitable to fer ciutat.

This observation can be extended to challenge the claim that postmodern consumer culture bestows powers on those who are considered to be exotic (Featherstone 1992). From the perspective of those evicted from Es Barri, such claims might sound like vindications for practices that reduce them to an "other" and even further to an "aesthetic other" that is presentable on stage when the annual festes of the fashionable bar are held. But the events in Es Barri do not bestow power to the old residents. Instead, gentrification commoditises their lifestyles by turning them into a part of the historic heritage. At the same time, gentrification creates a marketable illusion of this evicted lifestyle available for consumption to those who can pay for it - the new residents and visitors. Those considered exotic end up being eradicated 
from the very social setting created through gentrification strategies that are not at all subtle. In fact, whereas the already stated strength of complexity and uniqueness argues against replication, the reduction and consumption of the "other" works as a means for quite the opposite, that is, the commercial mass replication of clichéd differences.

The immediate implications of this commoditisation of and in the neighbourhood are reflected in the increasing urban tourism policies that use the neighbourhood scale. They take advantage of its unevenly developed matter in order to create, if not a surplus through gentrification, then at least a surplus from its promise. This necessarily means the imposition of pressure on the practices of older residents, who suffer from degradation until they either confront or take advantage of the very same urban policy. As for the new residents, they are the ones who will take up the fer barri baton. It remains to be seen whether the new Es Barri will be strong enough to keep the newcomers attached to the neighbourhood and it will thus be possible to avoid future decay or whether another wave of gentrification will turn today's newcomers into the historic heritage of the future.

\section{REFERENCES}

AJUNTAMENT DE PAlmA, 1998, Memoria del Plan General de Ordenación Urbana. Palma de Mallorca, Ajuntament de Palma.

—, 1999, El Centre Històric de Palma: De la Rehabilitació Monumental a la Rehabilitació Integral, Història d'un Procés. Palma de Mallorca, Ajuntament de Palma.

AMER, Joan, 2006, Turisme i Política: L'Empresariat Hoteler de Mallorca. Palma de Mallorca, Documenta Balear.

ASSOCIACIÓ DE VEÏNATS DE CANAMUNT, 1993, Investigació sobre la Realitat Social i Demogràfica de Sa Gerreria: VIII Edició dels Premis Ciutat de Palma. Palma, Ajuntament de Palma.

BALTASAR, Basilio, et al., 1995, "Ciudad y turismo", in Fernando Pardo (ed.) et al., Palma, Ciutat del Segle XXI: Ciclo de Conferencias. Palma de Mallorca, Los Iconos de Ferón, 81-96.

BARTH, Fredrik, 1978, "Conclusions", in Fredrik Barth (ed.), Scale and Social Organization. Oslo, Universitetsforlaget, 253-273.

BERREMAN, Gerald D., et al., 1978, "Scale and social relations" [and comments and reply], Current Anthropology, 19 (2): 225-245.

BLÁZQUEZ, Macià, et al., 2002, El Tercer Boom: Indicadors de Sostenibilitat del Turisme de les Illes Balears 1989-1999. Palma de Mallorca, Ed. Lleonard Muntaner and CITTIB. 
BOISSEVAIN, Jeremy, 1984, "Ritual escalation in Malta", in Eric R. Wolf (ed.), Religion, Power and Protest in Local Communities. New York, Mouton, 163-183.

_- 1992, "Play and identity: ritual change in a Maltese village", in Jeremy Boissevain (ed.), Revitalizing European Rituals. London, Routledge, 136-154.

BOLETÍN OFICIAL DEL ESTADO, 2008, $27^{\text {th }}$ December, no. 312, available at $<$ http://www. boe.es/boe/dias/2008/12/27/pdfs/A52072-52074.pdf> (last accessed 09/07/2009).

BRENNER, Neil, 2001, "The limits to scale? Methodological reflections on scalar structuration”, Progress in Human Geography, 25 (4): 591-614.

CASASÚs, Josep M., 1996, Periodisme Català que Ha Fet Història. Barcelona, Proa.

CASTELLS, Manuel, 1991 [1972], La Cuestión Urbana. Madrid, Siglo XXI Editores.

COMAROFF, Jean, and John COMAROFF, 2003, "Ethnography on an awkward scale: postcolonial anthropology and the violence of abstraction”, Ethnography, 4 (2): 147-179.

FEATHerstone, Mike, 1992, Consumer Culture and Postmodernism. London, Sage Publications.

FRANQUESA, Jaume, 2005, Sa Calatrava Mon Amour: Etnografia d'un Barri Atrapat en la Geografia del Capital. Barcelona, Universitat de Barcelona, unpublished thesis.

— , 2007, "Vaciar o llenar o la lógica espacial de la neoliberalización”, Revista Española de Investigaciones Sociológicas, 118: 123-150.

FRANQUESA, Jaume, and Marc MORELL, 2005, "Heritage deviations in relation to town planning in Ciutat de Mallorca”, Journal of Mediterranean Studies, 15 (2): 427-462.

FrONTERA, Guillermo, 1975, Guía Secreta de Baleares. Madrid, Al-Borak.

FRONTUR (Movimientos Turísticos en Fronteras), 2008, Entradas de Turistas Según Comunidad Autónoma de Destino Principal. Instituto de Estudios Turísticos, Ministerio de Industria, Turismo y Comercio, Gobierno de España. Available at <http://www.iet.tourspain. es/paginas/rsvisor.aspx?ruta =\%2fFrontur\%2fEstructura $\% 2$ fAnual $\% 2$ fEntradas + de + turistas + seg\%u00fan + Comunidad + aut\%u00f3noma + de + destino + principal. + + Ref.204\&par $=1$ \&idioma $=$ en-US\&anio $=2008>($ last accessed 30/01/2009).

GLASS, Ruth, 1964, "Introduction: aspects of change”, in Centre for Urban Studies (ed.), London: Aspects of Change. London, MacGibbon \& Kee, xiii-xlii.

HANNERZ, Ulf, 2003, "Macro-scenarios: anthropology and the debate over contemporary and future worlds", Social Anthropology, 11 (2): 169-187.

HARVEY, David, 2003, The New Imperialism. Oxford, Oxford University Press.

HERZFELD, Michael, 2001, Anthropology: Theoretical Practice in Culture and Society. Oxford, Basil Blackwell Publishing.

HOWITT, Richie, 2000, "Scale", in John A. Agnew, Katharyne Mitchell and Gerard Toal (eds.), A Companion to Political Geography. Oxford, Basil Blackwell Publishing, 138-157.

INSTITUT D'ESTRATÈGIA TURÍSTICA, 2008, Ocupació Laboral al Sector Turístic de les Illes Balears 2008. Conselleria de Turisme, Govern de les Illes Balears. Available at < http://www. inestur.es/documentos/855_ca.pdf> (last accessed 09/07/2009).

KNAUFT, Bruce M., 2006, "Anthropology in the middle", Anthropological Theory, 6 (4): 407 430.

LEES, Loretta, et al., 2008, Gentrification. New York, Routledge.

LLOYD, Richard, 2006, Neo-Bohemia: Art and Commerce in the Postindustrial City. New York, Routledge.

MANERA, Carles, and Jaume GARAU-TABERNER, 2009, "The transformation of the economic model of the Balearic Islands: the pioneers of mass tourism, 1960-2000", in 
Luciano Segreto, Carles Manera and Manfred Pohl (eds.), Europe at the Seaside: The Economic History of Mass Tourism in the Mediterranean. Oxford, Berghahn Books, 31-48.

MANSON, Steven M., 2008, "Does scale exist? An epistemological scale continuum for complex human-environment systems", Geoforum, 39: 776-788.

MARSTON, Sallie A., 2000, "The social construction of scale”, Progress in Human Geography, 24 (2): 219-242.

MARSTON, Sallie A., et al., 2005, "Human geography without scale", Transactions of the Institute of British Geographers, 30 (4): 416-432.

MARSTON, Sallie A., and Neil SMITH, 2001, "States, scales and households: limits to scale thinking? A response to Brenner", Progress in Human Geography, 25 (4): 615-619.

MORELL, Marc, 2000, The Eco-tax in the Balearics: A Case Study where Politics and Environment Meet Tourism. London, University of North London, MA final dissertation.

NEVELING, Patrick, and Carsten WERGIN, 2009, "Projects of scale-making: new perspectives for the anthropology of tourism", this volume.

RANKIN, Katharine N., 2003, "Anthropologies and geographies of globalization”, Progress in Human Geography, 27 (6): 708-734.

RUIZ VIÑALS, Carme, 2000, L'Urbanisme de la Ciutat de Palma de Mallorca. Palma de Mallorca, Editorial El Far.

RULLAN SALAMANCA, Onofre, 1999, "De la cova de Canet al tercer boom turístic: una primera aproximació a la geografia històrica de Mallorca”, in El Medi Ambient a les Illes Balears. Qui És Qui? Palma de Mallorca, "Sa Nostra”, Obra Social i Cultural de la Caixa de Balears.

SCOTT, James C., 1998, Seeing Like a State: How Certain Schemes to Improve the Human Condition Have Failed. New Haven, Yale University Press.

SELWYN, Tom, 2000, "The de-mediterraneanisation of the Mediterranean?", Current Issues in Tourism, 3 (3): 226-245.

SHAW, Gareth, and Allan M. WILlIAMS, 2002 [1994], Critical Issues in Tourism: A Geographical Perspective. Oxford, Blackwell Publishing.

SMITH, Neil, 1984, Uneven Development: Nature, Capital and the Production of Space. Oxford, Basil Blackwell Publishing.

—, 1996a, The New Urban Frontier: Gentrification and the Revanchist City. London, Routledge.

_ $1996 \mathrm{~b}$, "Spaces of vulnerability: the space of flows and the politics of scale", Critique of Anthropology, 16 (1): 63-77.

TSING, Anna, 2000, “The global situation”, Cultural Anthropology, 15 (3): 327-360.

UITERMARK, Justus L., 2002, “Re-scaling, 'scale fragmentation' and the regulation of antagonistic relationships”, Progress in Human Geography, 26 (6): 743-765.

VALDIVIELSO, Joaquín, 2001, "Poder y hegemonía en la batalla de la Ecotaxa", in Joaquín Valdivielso (ed.), ¿A Qué Llamamos Ecotasa?. Palma de Mallorca, Monograma, 9-40.

— 2005, "The Balearic islands within the framework of the Mediterranean: an enigmatic model", in Tribuna de la Mediterrània. Available at < http://www.tribunadelmediterraneo. com/pons.php3?idi $=$ ingles\&codigo $=11$ \&indice $=87>($ last accessed 09/07/2009) .

WHITEHEAD, Mark, 2003, "Love thy neighbourhood: rethinking the politics of scale and Walsall's struggle for neighbourhood democracy", Environment and Planning A, 35 (2): 277-300.

WOLF, Eric R., 1982, Europe and the People Without History. Berkeley, University of California Press. 
Fent barri: políticas de turismo patrimonial e configuração da escala do bairro na Cidade de Maiorca - Marc Morell - Universitat de les Illes Balears, Espanha • marc.morell@uib.cat

Este artigo explora os significados da expressão local fer barri (fazer o bairro) numa zona em processo de nobilitação no centro histórico da Cidade de Maiorca (Espanha). Após um exame detalhado da relação entre o fer barri e o turismo em Maiorca, são aqui analisadas as tensões entre os programas de planeamento urbano lançados pelas autoridades públicas sobre este território rico em património e, por outro lado, as práticas dos seus habitantes. Defendo que o conceito de "configuração da escala do bairro" é o que melhor se adequa às relações sociais a que este contexto urbano local dá forma, dada a hierarquia de forças (locais, regionais, nacionais e globais) a que está sujeito. Programas de intervenção urbana e organizações de residentes definem a escala do bairro de formas incompatíveis. Alguns seguem uma lógica dependente do turismo e procuram promover o bairro destacando o seu património ou a sua centralidade, ou ainda pela realização de grandes eventos. Paralelamente às políticas estatais, aos negócios turísticos e às empresas imobiliárias, também alguns movimentos urbanos, frequentemente retratados como grupos de oposição, mantêm noções próprias sobre o que significa fer barri. Esta coincidência é contraditória, uma vez que, no seu esforço de valorização do bairro como forma de contestação da acumulação de capital, estes movimentos urbanos podem involuntariamente abrir caminho à sua renovação e à sua nobilitação. Deste modo, a análise exaustiva da expressão local fer barri revela projectos contrastantes de configuração da escala do bairro.

PALAVRAS-CHAVE: nobilitação, turismo patrimonial, renovação urbana local, escala e organização social, movimentos urbanos. 